\title{
Iluntasunetik argirantz, genoma ez-kodetzailea kodetuz
}

\author{
From darkness to light, codifying the non-coding genome
}

\author{
Naroa Gimenez-Camino ${ }^{1^{*}}$, Ane Amundarain ${ }^{1^{*}}$, Xabier Agirre $^{1}$ \\ 1.- CIMA, Universidad de Navarra, IdiSNA, Ciberonc. \\ *NG eta AAk lan bera egin dute. \\ xaguirre@unav.es
}

\section{Laburpena}

\begin{abstract}
Azken urteetan gertatu den genomen ikerketarako teknologien garapen ikaragarriak zientzialariek genoma, transkriptoma eta proteomaren inguruan zuten ikuspegia errotik aldatzea eragin du. DNAren eta RNAren sekuentziazio masiboei esker, ordura arte "DNA zabor" bezala ezagututako guneetatik transkribatutako proteinarik kodetzen ez duten milaka RNA ez-kodetzaile (ncRNA) detektatu dira, genomen inguruko ikuspegi proteozentrikoa alboratuz eta RNA ez-kodetzaileak, bereziki luzeak (long non-coding RNA, IncRNA), ikertzaileen fokuan jarriz. Era berean, azken ikerketek geneen adierazpenerako ezinbestekoak diren transkripzio- eta itzulpen-prozesuen erregulazioak duen garrantzia ere agerian jarri dute. Erregulazio-mekanismo nagusietako bat DNAn, RNAn eta proteinetan aurkitu diren marka biokimiko itzulgarriek osatzen dute; eta horien ikerketak epigenomika, epitranskriptomika eta epiproteomika izeneko biologiaren atal berrien sorrera ekarri du. Hala ere, ikerketa gehienak epigenoma eta epiproteomaren inguruan egin direnez, marka horien ezarpenak RNAn duen eraginak ezezaguna izaten jarraitzen du. Emaitza hauek tarteko, zalantzarik gabe RNAren biologiaren esparruan galdera asko dago oraindik erantzuteko. Hori delaeta, berrikuspen honetan aipatutako RNAren biologiaren bi esparru berrietan fokuratu gara, horien inguruan ezaguna dena jasoz eta giza gaixotasunekin, zehazki leuzemia mieloide akutuarekin (Acute myeloid leukemia-AML), duten harremana laburbilduz. Oraindik alor ezezagunak izanik, ikertzaileek tamaina eta konplexutasun handiko erronka dute aurrean RNAren biologiaren mundu ilun hau argitu ahal izateko eta emaitza hauek arlo klinikora bideratzeko.
\end{abstract}

Gako-hitzak: RNA, IncRNA, epitranskriptoma, AML

\section{Abstract}

The development of Next Generation Sequencing (NGS) technologies has made scientists radically change their vision about the genome, transcriptome and proteome. Massive DNA and RNA sequencing analyses have detected thousands of novel non-coding RNAs (ncRNAs) transcribed from genome regions known earlier as "junk DNA". These results have led scientists to put aside the proteocentric view of genomics and have highlighted the relevance of non-coding transcripts, especially of long non-coding RNAs (IncRNAs). Besides, recent research reveals the importance of regulation of transcription and translation processes, which are essential to gene expression. One of these principal regulatory mechanisms is based on the reversible biochemical modifications found in DNA, RNA and proteins and their research have led to new biological mechanisms called epigenomics, epitranscriptomics or epiproteomics. However, most of this research has been 
conducted on DNA and proteins, and thus, the biological effect of these modifications in RNA remains unknown. Considering this, there are many questions to be answered in the context of RNA biology. In this review we will focus on the knowledge about the biology of IncRNAs and epitranscriptome, as well as their link to human diseases, in particular with Acute Myeloid Leukemia (AML). Undoubtedly, scientists have a great challenge to decipher the mysterious world of RNA biology and be able to transfer the results obtained in this area to the clinical practice of human tumors and diseases.

Keywords: RNA, IncRNA, epitranscriptome and AML

Bidalia: 2018ko abenduaren 26an.

Onartua: 2019ko apirilaren 15ean.

https://doi.org/10.26876/osagaiz.1.2019.220

\section{Sarrera}

Biologia zelularraren eta molekularraren alorrean oinarrizko erronketako bat giza genomaren elementu funtzionalen identifikazioan aurrerapauso trinkoak egitea da. Orokorki, giza genoma bi elementu mota nagusitan bereiz daiteke; alde batetik, gene modura adierazten diren eta transkripzio- eta itzulpen-prozesuen ondoren proteina ematen duten elementu edo geneetan, eta bestetik, gene horien erregulatzaile modura jokatzen duten elementuetan. Jakinik proteinak zirela azken finean zelularen barruko funtzioak burutzen zituztenak, hasiera batetik genoma ikertzen zuten ikertzaileen artean genomaren ikuspegi proteozentrikoa zabaldu zen, gerora biologia zelularraren dogma nagusietako bat izan dena: "Gene bat - proteina bat". Horrela, fokua proteinak kodetzen dituzten geneetan jarri zen, eta gene kodetzailerik identifikatu ez zen genomaren atalak "DNA zabor" bezala kontsideratu ziren. Zentzu horretan, 2003. urtean burututako Giza Genoma proiektuari esker giza genomako proteina-kodetzaileen gene kopurua zehaztasun handiz finkatzea lortu zen genoma osoa sekuentziatu ondoren (1). Hala ere, azken urteetan errendimendu altuko teknologien garapen ikaragarriak (errendimendu altuko DNA eta RNA sekuentziazioak) orain arteko genomaren ikuspegi proteozentrikoa zalantzan jartzea eragin du. Plataforma horiek RNAren transkripzioa modu global batean aztertzea ahalbidetu dute, genomaren \% 90 inguru transkribatzen dela frogatuz. Harrigarriki, portzentaje horretatik \% 2 bakarrik dagokie proteinak kodetzen dituzten geneei, genomatik transkribatzen diren RNA ez-kodetzaileen (ncRNA) ugaritasuna eta aniztasuna azaleratuz eta horiek zelularen identitate eta funtzioan izan dezaketen eragin zuzena azpimarratuz (2).

Baina zelularen biologiaren konplexutasuna ulertzeko zelulan ZER adierazten den jakitea ez da nahikoa, NOLA eta ZENBAT adierazten den ere jakitea ezinbestekoa baita. Hain zuzen, geneen adierazpena kontrolatzen duten bi mekanismo nagusiak DNA genomikotik RNArako transkripzioa eta RNAtik proteinarako itzulpena dira. Prozesu horiek maila ugaritan erregulatzen dira; horrela zelulak inguruko estimulu ezberdinei erantzuten die une bakoitzean behar dituen elementu zehatzen adierazpena erregulatuz. Erregulazio hori mekanismo ezberdinen bidez egiten bada ere, DNAn, RNAn eta proteinetan ezartzen diren marka biokimiko itzulgarri desberdinek garrantzi handia dute prozesu honetan. Marka horietako batzuk, esaterako DNAren metilazioa eta proteinen fosforilazioa edo ubikitinazioa, sakonki ikertu dira zelularen barruan ezinbesteko funtzioak dituztela erakutsiz. Zehazki, marka horiek ez dute DNAren, RNAren edo proteinaren sekuentzian eraginik, baina erabakigarriak dira elementu horien patua ezartzerakoan. Gaur egun erraza da DNA genomikoan zehar agertzen diren aldaketa biokimiko itzulgarri ezberdin hauek, epigenoma bezala ezagutzen duguna, bereiztea eta aztertzea. Antzekoa gertatzen da epiproteomarekin ere, hau da, zelula espezifikoen proteinen itzulpen ondorengo aldaketen analisiarekin. Bi alor nagusi horiek, epigenomikak eta epiproteomikak, eragin izugarria izan dute zelulen seinaleztapena, geneen erregulazioa eta minbiziaren biologia ulertzeko garaian. Alabaina, DNA eta proteinen bitartean dagoen biologia, RNAren mundua, ulertzeko ahalegin handiak egiten ari dira ikertzaileak gaur egun. Azken urteetan, 100 aldaketa kimiko baino gehiago antzeman dira RNAn, gehiengoak RNA ezkodetzaileetan aurkitu diren arren, (bai RNA erribosomikoan (RNAr), RNA transferentziazkoan 
(RNAt) edo RNA nuklear txikietan (snRNA-n)), RNA mezulariaren (RNAm) prozesamendu egokia (itzulpena eta moztitsasketa) burutzeko ere oso garrantzitsuak direla ikusi da (3). Horrela, 2012. urtean, lehen aldiz epitranskriptoma hitza sortu zen, RNAren aldaketa biokimikoak izendatzen zituena. Alegia, epitranskriptomak RNA molekulen konposizio kimikoan gertatzen diren aldaketa biokimikoak aztertzen ditu, RNAren funtzioa edo egonkortasuna aldatzeko potentziala dutenak eta funtsezkoak izango direnak (4).

Azterketa honetan minbiziaren inguruko ikuspegi proteozentrikoaz haratago joan nahi genuke, gene ez-kodetzaile hauek eta haien adierazpenaren erregulazioak tumoreen garapenean izan dezaketen garrantzia azpimarratuz. Erregulazio hori maila ezberdinetan eman daiteke eta esan bezala protagonista ugarirengan izan dezake eragina. Lan honetan, alde batetik, RNA ez-kodetzaile luzeen (IncRNA) ezaugarri nagusiak eta minbiziaren garapenean horiek duten garrantzia laburbiltzen saiatuko gara. Izan ere, gaur arteko emaitzek tumore solido zein hematologikoen garapenean hainbat RNA ez-kodetzaile luzek izan dezaketen paper kritikoa azpimarratu dute. Bestalde, epitranskriptomaren alorra ere pil-pilean dagoen garai honetan, zientzialariek interes handia dute RNA molekuletan dauden aldaketa biokimikoek izan dezaketen garrantziaren ikerketan. Orain arte RNAn aldaketa kimiko ugari deskribatu badira ere, gaur egun $N^{6}$ metiladenosinaren $\left(\mathrm{m}^{6} \mathrm{~A}\right)$ inguruan lortzen ari dira aurrerapauso handienak, aldaketa horrek RNA elementuen egituran eta adierazpenean eragin zuzena duela ikusi baita (5). Adibide modura, RNA ez-kodetzaile luzeek eta epitranskriptomak $\left(\mathrm{m}^{6} \mathrm{~A}\right.$ aldaketak) leuzemia mieloide akutuaren (acute myeloid leukemia, AML) garapenean izan dezaketen paper garrantzitsua berrikusiko dugu. Leuzemia mieloide akutua helduengan agertzen den jatorri mieloideko minbizi ohikoena da, bere ezaugarri nagusia hezur-muinean eta odolean gertatzen den zelula leuzemiko heldugabeen pilaketa izanik. Horren prebalentzia dela-eta, minbizi hematologikoen alorrean gehien ikerturiko tumoreen artean dago eta, ondorioz, RNA ez-kodetzaile eta epitranskiptomikaren alorrean aurrerapen esanguratsuak burutu dira azkenaldian AMLaren testuinguruan (6).

\section{RNA ez-kodetzaile luzeak (long non-coding RNA, IncRNA)}

Orokorki, RNA ez-kodetzaileak zelularen barruan proteinarik kodetzen ez duten transkripto genikoak dira. Horien gehiengoa aspalditik ezagunak diren eta zelularen barruan maila altuan adierazten diren "housekeeping" RNA ez-kodetzaileek osatzen dute, zeinetan RNAm-aren itzulpenerako ezinbestekoak diren RNAr eta RNAt, RNAren moztitsasketarako ezinbestekoak diren RNA nuklear txikiak (snRNA) eta RNAren eraldaketan parte hartzen duten RNA nukleolar txikiak (snoRNA) aurki ditzakegun (7). Hala ere, "housekeeping" RNA kategorian sartzen ez diren RNA ezkodetzaile mota ugari identifikatu dira, horiek sailkatzeko irizpide nagusia tamaina izanik: RNA ezkodetzaile laburrak ( $<200$ bp) eta RNA ez-kodetzaile luzeak ( 200 bp). Berriki, geneen adierazpenean eta gaixotasun ugariren garapenean funtzio garrantzitsuak dituzten RNA ezkodetzaile labur ugari deskribatu dira (small ncRNA). Azken ikerketek RNA ez-kodetzaile laburren dibertsitatea azpimarratu dute, kategoria horren barnean klase ugariko RNA ez-kodetzaileak bereiziz (mikroRNA, siRNA, piRNA...) (7). Horien artean, mikroRNAk dira orain arte gehien ikertu direnak eta minbiziaren testuinguruan tumore mota askotan miRNA horien adierazpenean asaldurak aurkitu dira, tumoreen garapenean duten funtzioa azpimarratuz (8).

Bestalde, RNA ez-kodetzaile luzeen (IncRNA) kategoriak 200 bp baino luzeagoak diren transkripto ez-kodetzaile guztiak biltzen ditu. LncRNAek ez dute 100 aminoazido baino luzeagoa den irakurketa irekiko sekuentziarik (ORF, open reading frame), orokorrean ez dute kodoi kontserbaturik eta ez dute homologiarik proteina datu-baseekin. Hori dela-eta, IncRNA hauen potentzial kodetzailea oso baxua da $(7,9)$. Baina pizten duten interesa ez dago proteinak kodetzeko duten gaitasunaren baitan, RNA molekula modura funtzionalak direla aurkitu izanaren baitan baizik. LncRNA funtzional edo RNA gene hauek klase modura definitzen dituzten hainbat ezaugarri komun partekatzen dituzte: alde batetik, kromatina-mailan transkribatzen diren DNA geneen marka epigenetiko berak dituzte, H3K4me3 (3. histonako 4. lisinaren trimetilazioa) promotorean eta H3K36me3 (3. histonako 36. lisinaren trimetilazioa) genearen gorputzean zehar, RNAm-aren antzera IncRNA gehienen transkripzioa RNA polimerasa II-k egiten du, 5' muturrean txapela dute, \% 40k 3' muturrean poliA 
isatsa dute eta gehienek introiak dituzte, moztitsasketa alternatiboa ohikoa izanik. Azkenik, haien adierazpena transkripzio-faktore ezagunen bidez erregulatua eta ia esklusiboki ehun espezifikoa izan ohi da $(7,10)$.

\section{IncRNAen sailkapena eta funtzionaltasuna}

LncRNAen taldean ezaugarri ezberdineko RNA klase ugari aurki daitezkeenez, haien sailkapenerako terminologia konplexua garatu da (9). Orokorrean, kontserbazio urria dutela eta funtzio oso ezberdinak bete ditzaketela kontuan izanda, sailkapenerako gehien erabilitako metodoa haien kokapen genomikoan oinarritzen da. Sailkapen horren arabera, IncRNAk kategoria orokor hauetan sailka daitezke: (A) "sense", harizpi bereko beste transkripto baten exoi batekin edo gehiagorekin gainezartzen direnak; (B) "antisense", aurkako harizpiko beste transkripto baten exoi batekin edo gehiagorekin gainezartzen direnak; (D) intronikoak, beste transkripto baten introi batetik eratorriak; (E) bidirekzional edo dibergenteak, promotorea aurkako harizpiko beste transkripto batekin partekatzen dutenez korregulatuak direnak, eta, azkenik, $(F)$ intergenikoak, beste bi geneen artean era independentean aurkitzen direnak (1. irudia) $(7,11)$. Azken horiek interes berezikoak dira transkripzio aktiboko marka histonikoak erakusten dituztelako, zelularen barruan funtzionalak direla iradokiz. Izatez, hainbat ikerketak zelularen oinarrizko bidezidorretan duten inplikazioa erakutsi dute, minbiziaren garapenean izan dezaketen garrantzia azpimarratuz (12).

Era berean, IncRNAen funtzio nagusia geneen adierazpena kontrolatzea denez (9), horretarako erabiltzen duten mekanismoaren arabera sailka daitezke, cis eta trans moduan jokatzen duten molekulak bereiziz. Cis motako IncRNAk transkripzio-gunean bertan betetzen dute beren funtzioa, inguruko geneen adierazpena erregulatuz. Adibide modura, orain arte gehien ikertu den XIST IncRNA daukagu, bi X kromosometako baten inaktibaziorako ezinbestekoa dena. Zehazki, XIST transkriptoa $X$ kromosoma inaktibotik transkribatzen da, kromosoma horri berari lotzean bere inaktibazio epigenetikoa martxan jarriz (13). Aldiz, trans motakoek geneen adierazpena genoma mailan erregulatzen dute, beren funtzioa ez baitute transkripzio-gunean bertan burutzen. HOTAIR IncRNA erregulazio mota horren adibide garbia da, 12. kromosoman kokatutako HoxC klusterretik adierazten baita, 2. kromosoman aurkitzen den HoxD klusterra erregulatzeko (14).

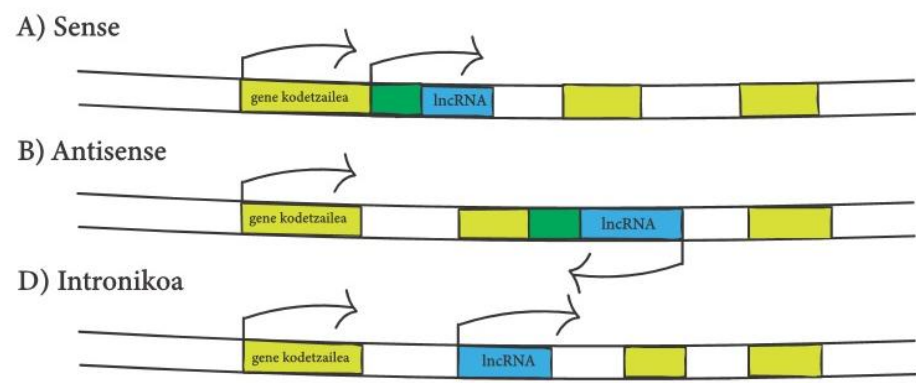

E) Bidirekzionala edo dibergentea

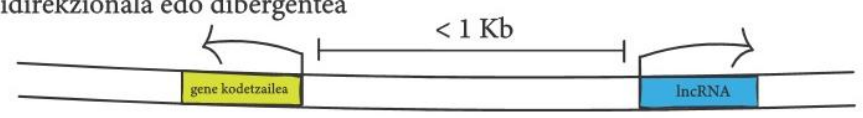

F) Intergenikoa

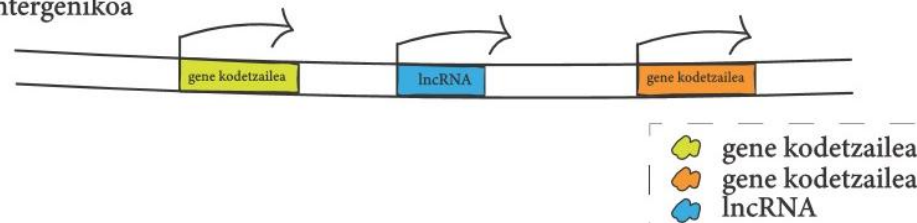

1. irudia: IncRNA mota ezberdinak genoman duten kokapenaren arabera, bost kategoriatan sailkatzen dira: (A) "sense", (B) "antisense", (D) intronikoak, (E) bidirekzional edo dibergenteak eta (F) intergenikoak. 
Orain arte identifikatutako IncRNAen kopuru handiak eta haien heterogeneotasunak zelularen barruan ezinbesteko funtzio ugari bete ditzaketela adierazten du. Alor honetan burututako ikerketek erakutsi dute orokorrean IncRNAen funtzio nagusia geneen adierazpena erregulatzea dela. Horretarako mekanismo nagusia genomaren gune konkretuetara kromatina eraldatzen duten konplexuak (geneen adierazpena erregulatzen duten proteina konplexuak) bideratzean datza (15). Konplexu horiek geneen adierazpena kontrolatzen dute epigenetikoki, hau da, geneak adieraztea edo isilaraztea eragiten dute horretarako marka espezifikoak ezarriz edo kenduz dagokien geneei. Marka horiek zelula bat bereiztean zelula alabetara pasatzen direla ikusi da, nahiz eta ez dagoen oso argi nola gertatzen den. Hala ere, IncRNAek beste hainbat funtzio betetzen dituzte zelularen nukleo eta zitoplasman (2. irudia), besteak beste, DNAren toleste eta isolamenduaren erregulazioa, RNAren transkripzio, moztitsasketa, itzulpen eta egonkortasunaren erregulazioa, egitura azpinuklearren antolakuntza, proteinen lokalizazioa egitura zelular jakinetara eta mikroRNAen lotura hauen funtzioa kontrolatzeko. Era berean, IncRNA batzuek peptido motzetara itzul daitezkeen ORF txikiak kodetu ditzakete (7).

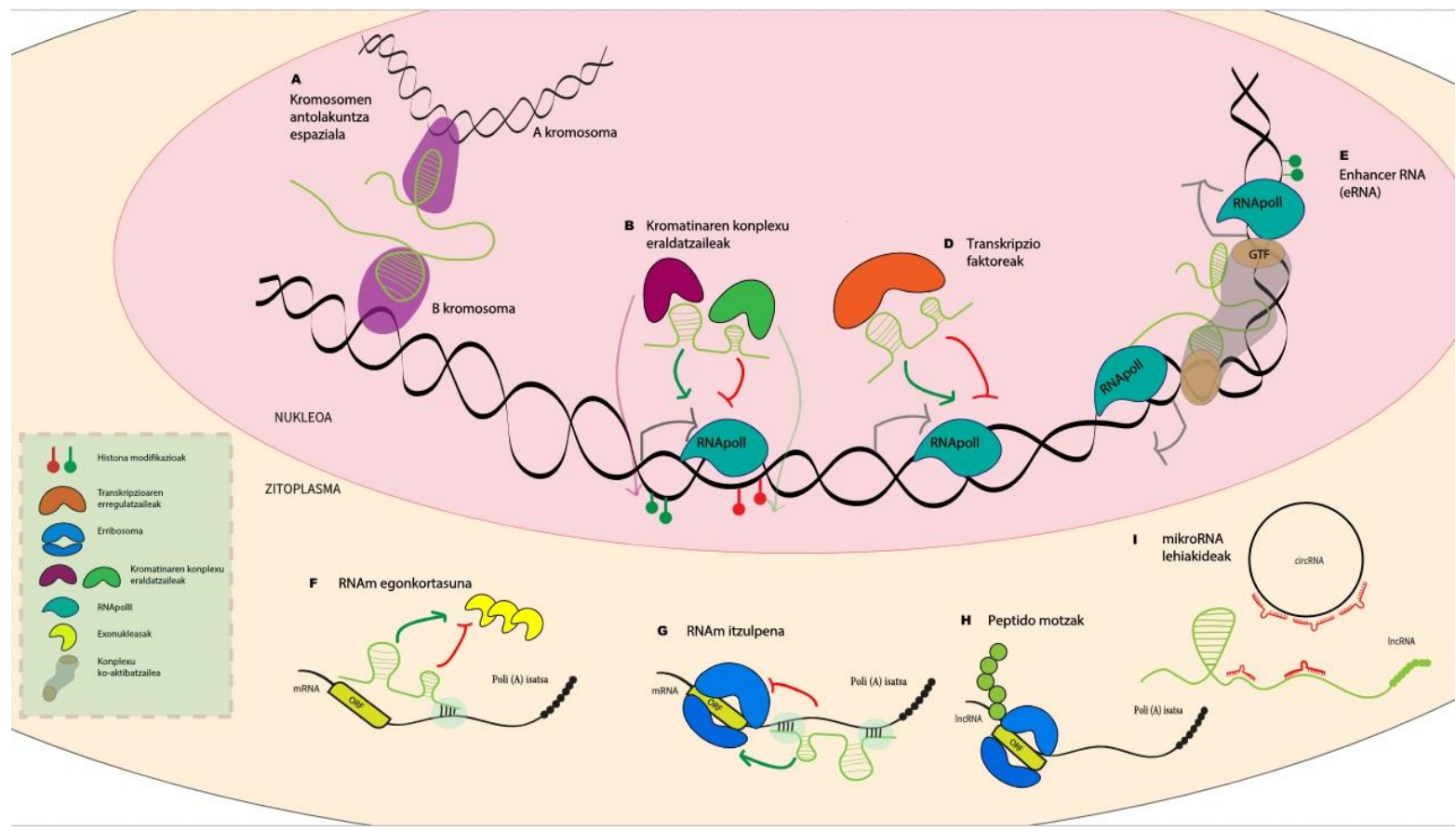

2. irudia: LncRNAen funtzioak. Alde batetik IncRNA nuklearrek geneen adierazpena kontrolatu dezakete: (A) Kromosomen antolakuntza espazialean eraginez, (B) kromatinaren konplexu eraldatzaileak genomaren gune konkretuetara bideratuz, (D) transkripzio-faktoreen jarduera erregulatuz, eta (E) geneen adierazpena areagotuz "enhancer" RNA (eRNA) modura jokatzean. Bestalde, IncRNA zitoplasmatikoek RNAm-aren adierazpena erregulatu dezakete: (F) RNAm-aren egonkortasuna erregulatuz, (G) RNAm-aren itzulpena erregulatuz, (H) IncRNA batzuek peptido motzetara itzul daitezkeen ORF kodetuz eta (I) mikroRNAekin lehiatuz beren ituei lotzeko. (38)-ko 1. iruditik eraldatua.

\section{LncRNAen erregulazioa eta minbizian duten papera}

LncRNA ugari deskribatu dira giza gaixotasunen garapenarekin erlazionatuta, bereziki minbiziaren testuinguruan. Zehazki, hainbat tumoretan onkogene, gene tumore-supresore eta eraldaketa metastatikoaren gidari diren IncRNAk deskribatu dira, horien desregulazioak gaixotasunaren garapenean duen garrantzia azpimarratuz. LncRNAen adierazpen akastun hori gene kodetzaileen kasuan bezala alterazio genomikoen, erregulazio epigenetikoaren, transkripzio-faktoreen edo egonkortasunean eragina duten faktoreen jardueraren ondorioa izan daiteke. Hau da, IncRNAek gene kodetzaileen adierazpena erregulatu ahal duten bezala, haiek ere zorrozki erregulatuak dira, orain arte zelularen barruko prozesuen erregulazioaren inguruan jakina zenari konplexutasun-maila 
berri bat gehituz (7). Horren adibide garbiak MEG3 (tumore-supresorea) eta ANRIL (onkogenea) IncRNAk dira.

MEG3 Maternally expressed gene 3 (MEG3) tumore-supresore modura deskribatutako lehen IncRNA da (3A. irudia). Minbizi mota ugaritan MEG3aren adierazpena era adierazgarrian murrizten dela deskribatu da; hala nola garuneko hainbat tumoretan, gibel, bular, giltzurrun, birika eta prostatako minbizietan, baita mieloma anizkoitza, sindrome mielodisplasikoa eta AML bezalako minbizi hematologikoetan ere $(7,16)$. AMLaren testuinguruan MEG3aren adierazpen murriztua eta promotorearen hipermetilazioa gaixo hauen pronostiko txarreko adierazle modura deskribatu dira (17). Zehazki, MEG3ak tumoreen garapena galarazteko p53 proteina tumore-supresore ezagunaren menpekoak diren zein p53rekiko independenteak diren bidezidor zelularrak aktibatzen dituela deskribatu da. Alde batetik, p53 degradatzen duen MDM2 proteinaren mailak murrizten ditu, p53 egonkortuz eta degradaziotik babestuz. Gainera, p53 proteinaren mailak igo, p53 menpeko transkripzioa aktibatu eta $\mathrm{p} 53$ bere gene ituen promotoreetara lotzeko gaitasuna handitzen du. Izatez, MEG3aren gainadierazpen ektopikoak p53ren pilaketa eragiten du, zelulen proliferazioa galaraziz. Azkenik, retinoblastomaren (RB) bidezidorra, eta ondorioz, zelulen proliferazioa erregulatzen dituela deskribatu da (16). Orotara, MEG3ak giza zelulak minbizi bihurtzetik babesten ditu.

\section{A}

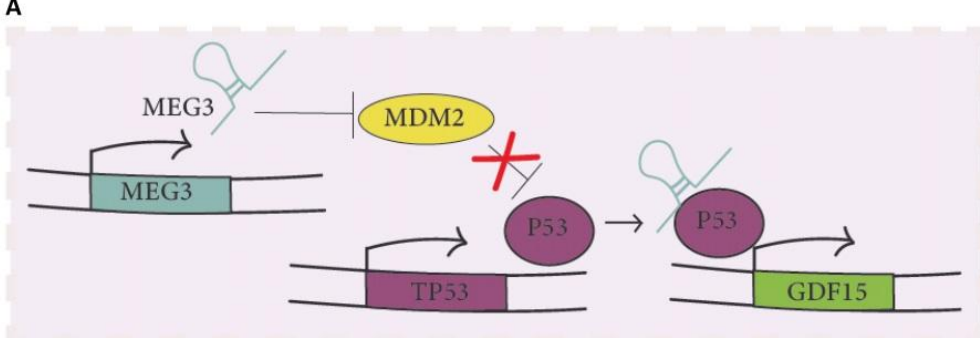

B

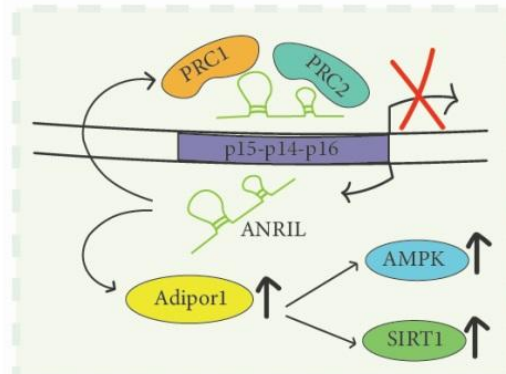

3. irudia: AMLen eragin tumore-supresorea edo onkogenikoa duten IncRNAen funtzioen irudikapen eskematikoa. (A) MEG3 IncRNA tumore-supresorearen p53 menpeko funtzioak. Alde batetik, MEG3k p53 degradatzen duen MDM2 proteinaren mailak murrizten ditu, p53 egonkortuz eta degradaziotik babestuz. Gainera, p53 proteinaren mailak igo, p53 menpeko transkripzioa aktibatu eta p53 bere gene ituen promotoreetara lotzeko gaitasuna handitzen du. (B) ANRILen funtzio onkogenikoak. ANRIL INK4 kluster tumore-supresorearekiko "antisense" transkribatzen da eta klusterra isilarazten du Polycomb konplexuak (PRC1 eta PRC2) bertara bideratuz. Gainera, AMLan ematen den ANRILen gainadierazpenak AdipoR1 hartzailea gainadierazten du, zeinak zelularen seneszentzia eta metabolismoa erregulatzen duten AMPK eta SIRT1en adierazpena sustatzen duen ondorio onkogenikoekin. (7)-ko 2. iruditik eraldatua.

ANRIL Antisense Non-coding RNA in the INK4 Locus (ANRIL) edo CDKN2B-AS1 p15INK4b-p14ARFp16INK4a klusterrarekiko "antisense" transkribatzen den funtzio onkogenikodun IncRNA da (3B. irudia). Kluster honetako INK4 proteinek funtzio tumore-ezabatzaile garrantzitsua dutela deskribatu da. Zehazki, p15 eta p16k zelulen proliferazioa bultzatzen duten CDK4 eta CDK6 ziklina menpeko kinasak inhibitzen dituzte. Aldiz p14ARFk, MEG3aren kasuan bezala, MDM2 proteinaren mailak murrizten ditu p53 egonkortuz (18). Proteina horiek garapen normalean zehar ez dira adierazten eta zahartzaroan edo estimulu onkogenikoen ondorioz bakarrik aktibatzen dira. Hain zuzen, lokus horren adierazpena Polycomb konplexu errepresiboek (PRC1 eta PRC2) zorrozki kontrolatzen dute, baldintza normaletan kluster osoa isilaraziz. ANRIL IncRNA Polycomb konplexuak kluster honetara 
bideratzeko ezinbestekoa dela erakutsi da. Era berean, ANRILaren isilarazpenak Polycomb konplexuen lotura blokeatzen du, INK4 proteinen adierazpena areagotuz eta zelulen proliferazioa blokeatuz $(18,19)$. AMLaren kasuan, ANRILaren adierazpena areagotuta dagoela ikusi da. Gainadierazpen horrek ondorio onkogeniko nabarmenak ditu; izan ere, ANRILak leuzemiaren garapena eragin dezake, INK4 klusterraren adierazpena eta zelulen seneszentzia murriztuz, horien proliferatzeko gaitasuna areagotuz eta zelularen metabolismoa erregulatuz (20). Zehazki, ANRILaren gainadierazpenak glukosaren metabolismoan zuzenean inplikatuta dagoen AdipoR1 hartzailea (adiponektina hartzailea 1) gainadieraztea eragiten du. Horrek, era berean, leuzemiaren tratamenduan itu garrantzitsuak diren eta zelularen seneszentzia eta metabolismoa erregulatzen duten AMPK eta SIRT1aren adierazpena sustatu eta ondorio onkogenikoak eragiten ditu (21).

Zalantzarik gabe, emaitza hauek minbiziaren garapenean IncRNAek duten paper kritikoa deskribatzen dute, alor honetan haien ikerketak duen interesa azpimarratuz. Ildo horretatik, IncRNA identifikazioak eta orain arte ikertutakoek zelularen barruan funtzio garrantzitsuak betetzen dituztela ezagutzeak orain arteko genomen, transkriptomen eta gene-adierazpenaren erregulazioaren inguruko ikuspegia aldatzea eragin du. Lehen emaitza hauek etorkizunean aurkikuntza zirraragarri ugari egingo direla aurreikusten badute ere, oraindik IncRNA hauen ikerketaren hastapenetan gaude eta ikerketa asko dago egiteko. Hasteko, IncRNAen eta haien adierazpen-patroien identifikazio eta anotazio sistematikoa eta publikoa behar da. Orain arte identifikatutako IncRNA kopurua oso handia bada ere, haien adierazpena oso ehun- eta baldintzaespezifikoa denez, ehun ezberdinetan eta zelula-estimulu ezberdinen aurrean jartzean (gaixo/osasuntsu, farmakologikoki tratatua/kontrola...) adierazten diren IncRNAen deskribapena ezinbestekoa da. Horrez gain, gene kodetzaileek bezala, IncRNAek ere transkripto ezberdinak eman ditzakete mekanismo ezberdinen ondorioz, transkripto horien guztien identifikazioa eta haiengan eragiten duten mekanismoen ezagutza beharrezkoa izanik. Era berean, IncRNAek zelulan betetzen dituzten funtzioak ezagutzeko ezinbestekoa da ikerketa funtzionalak egitea.

Giza gaixotasunei dagokienez, horietan identifikatutako IncRNAk haien diagnostiko goiztiarrerako biomarkatzaile gisa, pazienteen pronostikorako edo gaixotasun horiei aurre egiteko itu terapeutiko gisa erabili daitezkeela frogatzen duten ikerketak ezinbestekoak dira (7). Zentzu horretan, klinikara eramatea lortu den lehen IncRNA prostatako minbiziaren detekzio goiztiarrerako erabiltzen den PCA3 (Prostate Cancer Antigen 3) IncRNA da. PCA3aren adierazpena prostata-espezifikoa da, eta prostatako ehun osasuntsuekin alderatuta, prostatako tumoreen $\% 90$ baino gehiagotan haren adierazpena 60-100 aldiz handituta dagoela ikusi da. PCA3aren funtzioa ezezaguna den arren, biomarkatzaile gisa duen potentziala ikusita gernuko PCA3aren detekzioan oinarritzen den prostatako minbiziaren diagnostikorako test klinikoa garatu da (Progensa PCA3 urine test); gaur egun errutinazko test modura erabiltzen da bere sentikortasun altuagatik eta erraz egin daitekeen proba kliniko bat delako $(9,22)$. Beste zenbait minbizitan ere diagnostikorako zein pronostikorako baliagarriak izan daitezkeen IncRNAk identifikatu dira, baina oraindik ikerketa gehienak maila preklinikoan burutu direnez, paziente kopuru handiekin egindako azterketa kliniko kontrolatuak beharrezkoak dira emaitza itxaropentsu hauek arlo klinikora eramateko (9).

Era berean, RNAn oinarritutako terapien garapena oraindik hastapenetan badago ere, IncRNA ugarik minbiziaren garapenarekin duten harreman estuak eta horietako askok zelula espezifikoetan duen adierazpenak ikerketa-alor ezin interesgarriagoa bihurtzen dute minbiziaren aurkako borrokan terapia zuzenduen garapenerako (23).

Horrez gain, azken ikerketek IncRNAen adierazpena epitranskriptomikoki ere erregulatuta dagoela erakutsi dute, transkriptoma osoan zeharreko ikerketei esker milaka IncRNAtan marka epitranskriptomikoak aurkitu baitira (24). Zalantzarik gabe, harreman estua dago RNAren biologiaren bi alor horien artean, horien ikerketak duen interesa azpimarratuz.

\section{Epitranskriptomika}

Orain gutxi arte, zelulen informazio biologikoa DNAtik eratorritako kode genetikoaren barruan zegoela uste zen. Baina, azken urte hauetan ikertzaileek epitranskriptomikaren arloan jarri dute fokua, RNAren modifikazio kimikoetan; izan ere, aldaketa horiek transkripzio ondorengo prozesu 
guztietan eragina dutela ikusi da, azkenik proteinen sintesiaren dibertsifikazioan eraginez (25). RNAren modifikazio guztien artean, RNA eukariotoaren metabolismoan eta funtzioan eragina duten batzuk aurkitu dira, besteak beste, $\mathrm{N}^{6}$-metiladenosina $\left(\mathrm{m}^{6} \mathrm{~A}\right), 5$-metilzitosina $\left(\mathrm{m}^{5} \mathrm{C}\right)$, uridinaren $(\mathrm{U})$ isomerizazioa pseudouridinara $(\psi)$ edo $N^{1}$-metiladenosina $\left(m^{1} A\right)$ (4. irudia), modifikazio hauek batez ere, RNAm eta IncRNA bezalako RNA ez-kodetzaileetan agertzen direlarik. RNAren ezaugarri bereziak direla-eta, (bizi laburra, oso egituratua, gune zelular ezberdinen artean mugikorra), RNA mailako erregulazio hau oso sentikorra eta dinamikoa dela ikusi da. Zehazki, modifikazio bakoitzak bere efektua mekanismo ezberdin baten bidez lortzen duela deskribatu da, baina testuinguruaren arabera mekanismo horiek desberdinak izan daitezke. Gainera, modifikazio horietako batzuk oso dinamikoak dira, zelulari inguruneko estimuluei era azkarrean erantzutea ahalbidetuz (26).

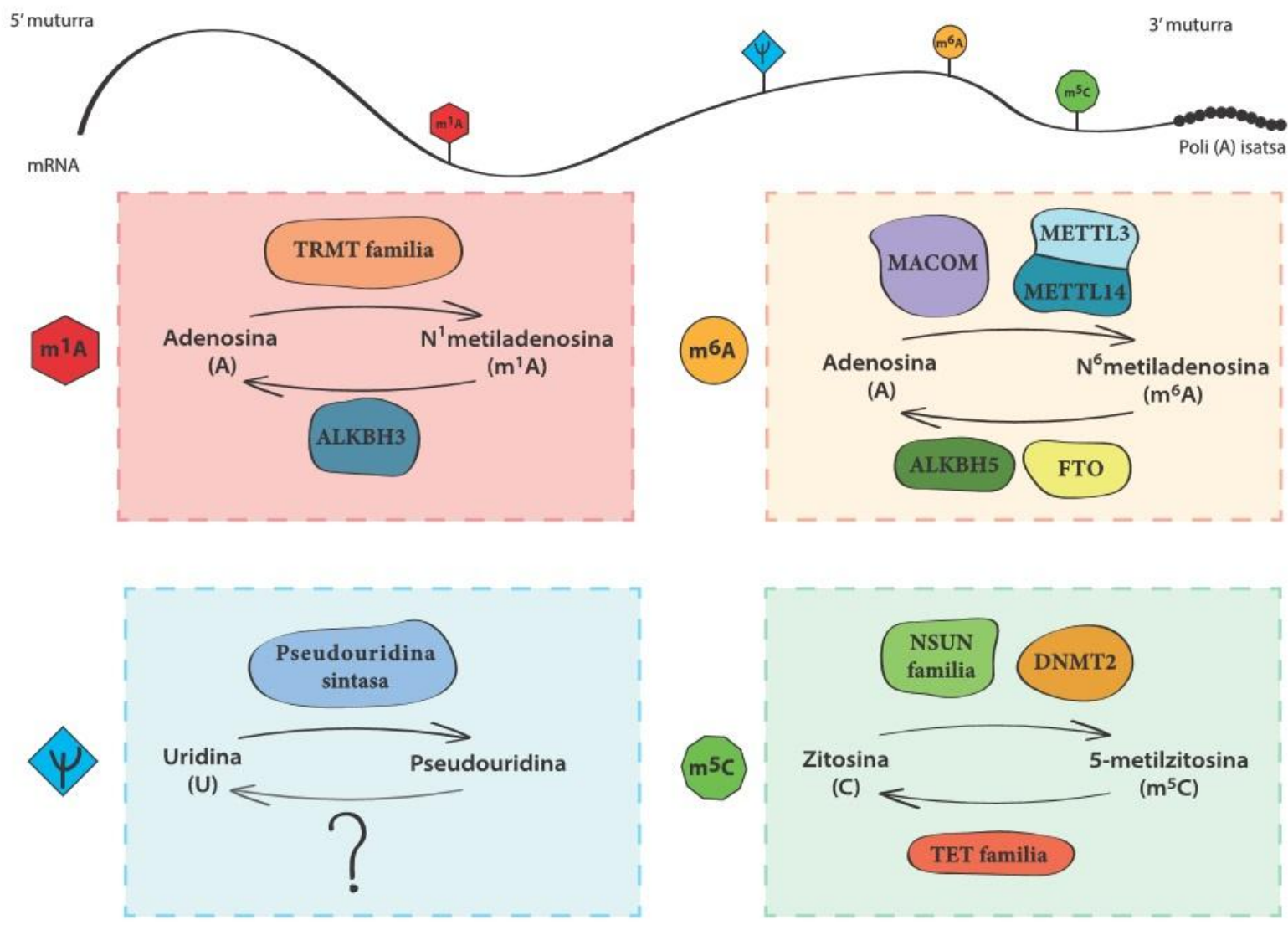

4. irudia: RNAren modifikazio kimiko ezagunen eta horien proteina idazle zein ezabatzaileen eskema. Agertzen diren modifikazio kimikoak $\mathrm{N}^{1}$-metiladenosina, $\mathrm{N}^{6}$-metiladenosina, uridina (U)pseudouridina eta 5-metilzitosina dira.

Ondorengo hauek dira RNAren, eta bereziki IncRNAen modifikazio epitranskriptomiko nagusiak:

$\mathbf{N}^{6}$-metiladenosina, aldaketa epitranskriptomiko nagusi eta ugarienetako bat da (25) eta GAC sekuentzian, adenosinaren 6. nitrogenoan metil talde baten ezarpenean datza $\left(m^{6} A\right)(26-28)(5$. irudia). Giza transkriptoen \% 25ean baino gehiagotan $10.000 \mathrm{~m}^{6} \mathrm{~A}$ aldaketa baino gehiago ikusi dira, eta ez hori bakarrik, aldaketa horiek 7.000 giza gene ezberdinetan gertatzen direla ikusi da. Zelulek aldaketa horren bidez, RNAren metabolismoa eta itzulpena azkartzen dute, aldaketa hori irakurtzeko gai den proteina espezifikoren bat dagoen bitartean, noski. Hortaz, $\mathrm{m}^{6} \mathrm{~A}$ edo bestelako aldaketak irakurtzeko gai diren proteinen identifikazioan eta karakterizazio funtzionalean dago gakoa; izan ere, proteina horiek markaturiko RNA horren patua zein izango den erabakiko baitute, amaierako RNA ez-kodetzaileen edo proteinen sintesia erregulatuz (27). Hainbat proteina ezberdin aurkitu dira $\mathrm{m}^{6} \mathrm{~A}$ aldaketaren idazle, irakurle eta ezabatzaile gisa parte hartzen dutenak. METTL3 entzima izan da lehena, metiltransferasa funtzioa du eta funtsezko proteina bezala deskribatu da $\mathrm{m}^{6} \mathrm{~A}$ aldaketa idazteko garaian. Horri, METTL14 entzima gehitu zaio, horrela METTL3rekin batera idazle konplexu bat osatuz (28). $\mathrm{m}^{6} \mathrm{~A}$ markaren idazle konplexuaren aktibitatea MACOM izeneko 
beste konplexu batek erregulatzen du, WTAP, VIRMA, CBLL1, ZC3H13 eta RBM15 proteinez osatuta (6). Aldi berean, $\mathrm{m}^{6} \mathrm{~A}$ marka espezifikoki identifikatzen duten proteinak deskribatu dira, irakurle moduan ezagutzen direnak, YTH familiakoak (YTHDC1-2 irakurle nuklearrak eta YTHDF1-3 irakurle zitoplasmatikoak). Proteina horiek $\mathrm{m}^{6} \mathrm{~A}$ marka funtzionala den edo ez erabakitzen dute, hau da, $\mathrm{m}^{6}$ Aren funtzio biologikoaren erantzuleak dira. Oraindik proteina horien inguruan ikerketa gutxi burutu bada ere, YTH familiako proteinek RNAren metabolismoko pauso ugaritan parte hartzen dutela deskribatu da. Esaterako, YTHDF1 eta 2 irakurle zitoplasmatikoek RNAm-aren itzulpena sustatu eta RNAm-aren egonkortasuna erregulatzen dute hurrenez hurren (29, 30). Aldiz, YTHDC1 irakurle nuklearra ezinbestekoa da preRNAm-aren moztitsasketa alternatiboa era egokian burutzeko (30). Moztitsasketa alternatiboaren erregulazioa RNAm-aren degradazioarekin zuzenki erlazionatuta dagoenez, $\mathrm{m}^{6} \mathrm{Ak}$ RNAm-aren egonkortasunean eragin zuzena duela ikusi da, horren adierazpen normalerako beharrezkoa izanik (27). Bestalde, $\mathrm{m}^{6} \mathrm{~A}$ aldaketa dinamikoa eta itzulgarria dela ikusi da, FTO eta ALKBH5 demetilasak izanik marka hau kentzearen erantzule zuzenak (28).

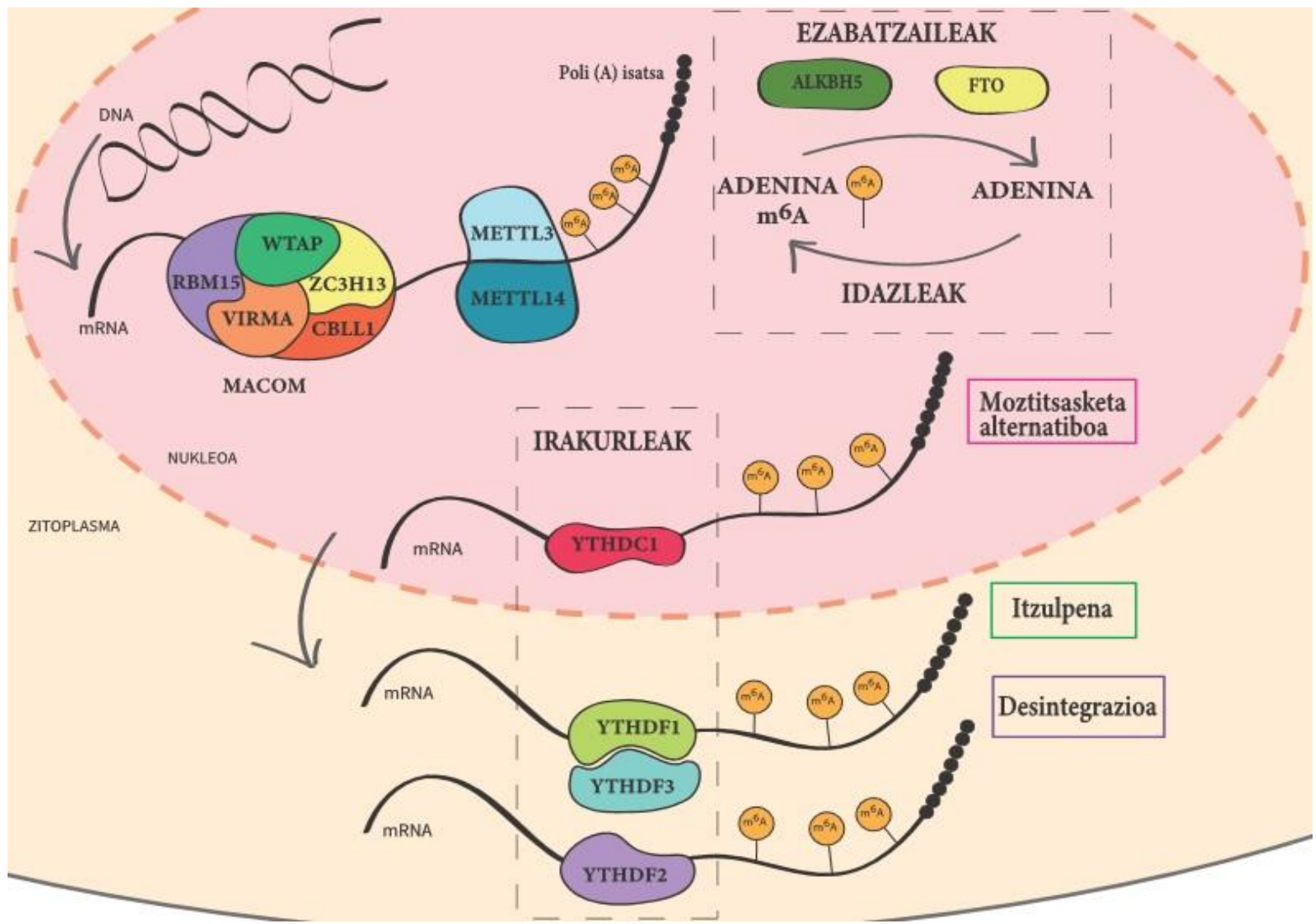

5. irudia: $m^{6} A$ modifikazioa eta horrek RNAren adierazpenean duen eginkizuna. $m^{6} A$ modifikazioa METTL3 eta METTL14 metiltransferasek osatutako konplexu katalitikoak ezartzen du, eta aitzitik, marka epitranskriptomiko hau FTO eta ALKBH5 proteina demetilasek ezabatzen dute. MACOM konplexua WTAP, RBM15, VIRMA, ZC3H13 eta CBLL1 proteinez osatuta dago eta METTL3/14 konplexuaren aktibitatea erregulatzen du. Aldi berean, YTH familiako proteinak $\mathrm{m}^{6} \mathrm{~A}$ markaren irakurleak dira.

Nukleoan YTHDC1 proteina irakurleak preRNAren moztitsasketa alternatiboa suspertzen du. Zitoplasman, aldiz, RNAren itzulpena YTHDF1 eta YTDHF3 proteinek estimulatzen dute, eta YTHDF2k, aldiz, RNAren egonkortasuna erregulatzen du.

Orain arte ezagutzen den $\mathrm{m}^{6} \mathrm{~A}$ marken gehiengoa RNAm-an aurkitu bada ere, funtzio zelular ezagunak dituzten IncRNAetan ere detektatu dira berriki. Esaterako, RNAm-aren transkripzioa eta moztitsasketa erregulatzen duen MALAT1 IncRNAn (Metastasis Associated lung adenocarcinoma transcript 1) hainbat $\mathrm{m}^{6} \mathrm{~A}$ gune aurkitu dira, MALAT1 transkriptoaren bigarren mailako egitura, eta ondorioz funtzioa, mantentzeko ezinbestekoak direnak (31). Era berean, XIST RNA ez-kodetzaile nuklearrean ere $\mathrm{m}^{6} \mathrm{~A}$ gune ugari identifikatu dira, eta YTHDC1 proteina gune horietara batzea ezinbestekoa da X kromosoma baten isilarazpena era egokian burutzeko (29). Zalantzarik gabe, emaitza hauek $\mathrm{m}^{6} \mathrm{~A}$ markaren garrantzia islatzen dute RNAren prozesamenduan, haren funtzio ugariak zehazteko ikerketa gehiagoren beharra azaleratuz. 
$\mathbf{N}^{1}$-metiladenosina, adenosinaren 1. nitrogenoan metil talde baten ezarpenean datza $\left(\mathrm{m}^{1} \mathrm{~A}\right)(32)$. Oraindik ez dago guztiz argi zein metiltransferasa proteinak katalizatzen duen marka honen ezarpena RNAn $(25,26)$, baina azken ikerketek modifikazio honen proteina idazle zein irakurle posible batzuk deskribatu dituzte, TRMT familiakoak eta ALKBH3 hurrenez hurren (33). Azken ikerketen arabera, RNA baseen parekatzea eten eta RNA harizpi bikoitzen banaketa eragin dezake $\mathrm{m}^{1} \mathrm{~A}$ aldaketak. Nahiz eta $7.000 \mathrm{~m}^{1} \mathrm{~A}$ aldaketa baino gehiago aurkitu diren RNA ez-kodetzaile luze eta kodetzaileetan, oraindik ikerketa gutxi burutu denez, $\mathrm{m}^{1}$ Aren funtzionaltasuna ez dago guztiz garbi nahiz eta seguruenik itzulpenaren sustapenarekin lotuta egon (32). Era berean, IncRNAetan marka honen presentzia oraindik ez da oso ondo aztertu, baina berriki buruturiko ikerketa batek MALAT1 IncRNAn $\mathrm{m}^{1} \mathrm{~A}$ guneak identifikatu ditu. Zalantzarik gabe etorkizunean, ikerketa gehiago egiten den heinean, marka hau IncRNA gehiagotan aurkitu eta horrela haren funtzioa zehazteko aukera hobeak izango dira (34).

5-metilzitosina, zitosinaren $5^{\prime}$ posizioan metil talde baten ezarpenean datza $\left(\mathrm{m}^{5} \mathrm{C}\right)$. Gutxienez 57 RNA metiltransferasa identifikatu dira giza zeluletan, haietatik 5 behintzat $\mathrm{m}^{5} \mathrm{C}$ aldaketan eragin zuzena dutenak; NSUN1/2/3/4/6/7, NSUN5a/b/c, DNMT2 (RCMT metiltransferasak) eta TET familiako proteinak hurrenez hurren. NSUN2k hainbat RNA ez-kodetzailetan 5-zitosina metilatu dezakeela ikusi da, eta horrek zelula amen garapenaren erregulazioan eta minbizi-zelulen garapen eta metastasian garrantzi handia duela deskribatu da. Aldiz, DNMT2k, DNA metiltransferasa bezala ezagutu den arren, RNAt eta RNAr-aren metilazioan ere parte hartzen duela ikusi da $(25,33,35)$. $\mathrm{m}^{5}$ Cren funtzio biologikoak RNA eukariotoan ezezaguna izaten jarraitzen du gaur egun (31). Bestalde, TET familiako TET1/2 eta TET3, $\mathrm{hm}^{5} \mathrm{C}$ (hidroximetilzitosina) bitartekari moduan erabiliz, $\mathrm{m}^{5} \mathrm{C}$ aldaketaren ezabatzaileak direla dirudi. Hau da, proteina horiek $\mathrm{m}^{5} \mathrm{Cetik} \mathrm{hm}^{5} \mathrm{Crainoko}$ bidea ahalbidetzen dute, ondoren $\mathrm{hm}^{5} \mathrm{Ctik}$ berriro zitosinarainoko buelta erraztuz (31). $\mathrm{m}^{5} \mathrm{C}$ detektatzeko teknika espezifikoekin transkriptoma ikertzean $\mathrm{m}^{5} \mathrm{C}$ marka ugari aurkitu dira hainbat IncRNAtan. Esaterako, modifikazio horrek XISTen funtzioa erregulatzen duela ikusi da; izan ere, in vitro ikerketetan XISTen $\mathrm{m}^{5} \mathrm{C}$ markaren presentziak PRC konplexu errepresiboak lotzea eragozten duela frogatu da (34).

Uridina (U)-pseudouridina $(\Psi)$, uridinaren isomerizazioa dela-eta suertatutakoa. Marka honen ezarpena RNA-gida menpekoa edo independentea izan daitekeela deskribatu da, snoRNP konplexu edo pseudouridina sintasa entzimek bideratua hurrenez hurren. Hala ere, oraindik ez da marka honen entzima irakurlerik ezagutzen, eta ez da ezabatzailerik aurkitzea espero itzulezina dela uste baita (33). Hala ere, gaixotasunekin erlazionatutako hainbat RNAtan pseudouridilazio-guneak antzeman dira, funtzio garrantzitsuak betetzen dituela iradokiz. Hala nola, pseudouridinak RNA baseen parekatzea aldatzen du, eta RNAren ezaugarri fisiko-kimikoetan ere eragin zuzena izan dezake, horrela, RNAren egitura aldatuz, baseen parekaketa hobetuz eta RNAren egiturari zurruntasuna emanez. Berriki, RNAm-an modifikazio hau jasaten duten ehunka posizio deskribatu dira, posizio hauek finkoak, induzigarriak zein ehun-espezifikoak direlarik (24). LncRNAei dagokienez, berriki burututako $\psi$-seq (pseudouridina-sekuentziazioa) ikerketei esker, pseudouridilazio guneak aurkitu dira hainbat IncRNAtan, besteak beste XIST eta MALAT1 IncRNAetan. Hala ere, modifikazio hauen funtzioa oraindik ezezaguna da gaur egun (24).

\section{Epitranskriptoma AMLan}

Epitranskriptomaren alorrean, $\mathrm{m}^{6} \mathrm{~A}$ aldaketa ugariena dela ikusi denez, esfortzu handiak egin dira horren detekziorako protokoloak ondo garatzeko. Zehazki, AMLan $\mathrm{m}^{6} \mathrm{Ak}$ RNAm-aren itzulpena desregulatzen duela deskribatu da. AMLan, METTL3 eta METTL14 gainadierazita daudela ikusi da progenitore hematopoietiko normalekin alderatuta $(6,36,37)$. METTL3 eta METTL14 transkripzioaren hasiera-guneetara lotzen dira bereziki, eta $\mathrm{m}^{6} \mathrm{~A}$ markaren ezarpen goiztiarrak AMLaren garapenerako beharrezkoak diren zenbait generen itzulpena bultzatzen du, hala nola cMYC, CBL2, PTEN, SP1 eta MYB. Gainera, gizakien eta arratoien zelula ama hematopoietikoetan (HSC) METTL3 eta METTL14 geneen jarduera katalitikoaren gainadierazpenak proliferazioa sustatu eta desberdintzapen mieloidea galarazten du (6). Era berean, zelula mieloideen desberdintzapenprozesuan METTL3 eta METTL14aren adierazpena nabarmen murrizten da. Are gehiago, HSC zeluletan METTL3 eta METTL14 geneen isiltzeak zelula horien proliferazioa gutxitu eta zelula 
mieloideen desberdintze-prozesua bizkortzen du $(6,36)$. Horrek, $\mathrm{m}^{6} \mathrm{~A}$ mailaren areagotzeak, HSC zeluletan desberdintzapen-ibilbide normala aldatzen duela adierazten du, horren ondorioa zelula progenitoreen pilaketa izanik. Emaitza hauek erakusten dute $\mathrm{m}^{6} \mathrm{~A}$ marka aldatzen duten entzimak itu interesgarria izan daitezkeela etorkizunean minbiziaren aurkako terapietan aurrerapauso garrantzitsuak emateko (6).

AMLaren alorrean aurrerapen garrantzitsuak egin dira, baita ere $\mathrm{m}^{5} \mathrm{Cren}$ karakterizazioan; izan ere, NSUN2 eta DNMT2 metiltransferasak 5- fluorourazilo eta 5-AZAren (Azacitidine) erantzunaren erregulazioarekin erlazionatuta daudela ikusi da. Bi farmako horiek sindrome mielodisplasikoa edo AML bezalako gaitz hematologikoen tratamenduan ohikoak dira, eta DNA eta RNA demetilatzen dute, bi horien metilazio-maila globalak murriztean hipometilazioa eraginez (35). Farmako horiek klinikan duten erabilera ikusita, marka epitranskriptomiko honen presentziak gaixotasunaren garapenean duen eragina ulertzea gakoa izan daiteke AMLan medikuntza pertsonalizatuari atea ireki eta paziente bakoitzari farmako egokiena emateko.

Bestalde, RNA aldatzen duten $\mathrm{m}^{1} \mathrm{~A}$ eta $\psi$ markek AMLan duten funtzio biologikoa ez da oraindik guztiz ulertu, seguruenik horien proteina idazle, irakurle eta ezabatzaile guztiak deskribatu ez direlako, eta, bestalde, aldaketa horiek detektatzeko baliabide optimoak falta direlako. Esaterako, errendimendu altuko sekuentziazioan (NGS) oinarritutako tekniken mapaketa-akatsen ondoriozko positibo faltsuak oraindik ezin daitezke modu errazean detektatu $(25,26)$. Marka horien ikerketa oraindik hastapenetan dagoenez, gaur egun zaila da gaixotasunen testuinguruan betetzen duten funtzioa ezagutzea, baina etorkizunean, ikerketa gehiago egiten den klinikaren alorrera eraman daitezkeen neurrian aurkikuntza zirraragarriak egitea espero da.

\section{Ondorioak}

Azken urteetan, teknologia berriei esker genetikaren arloan aurrerapen handiak egin diren arren, RNA ez-kodetzaileen eta epitranskriptomikaren alorrean oraindik galdera asko dago erantzuteko. Lehenik, epitranskriptoma zein IncRNAen ezagutzan aurrerapausoak emateko RNAren paisaia osoa ezagutzea ezinbestekoa da. Ikuspegi global hau beharrezkoa da; izan ere, zenbait RNA modifikaziok RNA mota desberdinen patua alda baitezakete, proteinen sintesian eragina izanik. Bestalde, IncRNA gehienen funtzioa oraindik ezezaguna da, eta hori gutxi balitz, RNAren modifikazioek ere beste konplexutasun-maila bat ezarri dute RNAren funtzio biologikoen erregulazioan (24). Horrez gain, IncRNAn edo RNAn ezarritako marka hauekin elkarri ekiten dioten faktore eta entzima zehatzak ezagutzea ere premiazkoa da haien funtzioa guztiz ulertzeko (27). Horrela, RNAren biologiaren aspektu ezberdinetan egindako ikerketa integratzea funtsezkoa izango da berari buruzko ulermena hobetzeko eta lortutako ezagutzak arlo klinikora eraman ahal izateko (26). Zalantzarik gabe, IncRNAen eta epitranskriptomaren aroaren hasieran gaude eta oraindik zientzialariek tamaina eta konplexutasun handiko erronka daukate RNAren biologia ulertzeko.

\section{Eskerrak}

Ikerketa hau Espainiako Hezkuntza eta Lanbide Heziketa Ministerioaren proiektuari (Ayuda para la Formación de Profesorado Universitario 2017, FPU2017/02733 Ane Amundarain Iraola) esker burutu da.

\section{Bibliografia}

1. Lander ES, et al. Initial sequencing and analysis of the human genome. Nature. 2001; 409: 860-921.

2. Mattick JS. Non-coding RNAs: The architects of eukaryotic complexity. EMBO Rep. 2001; 2: 986-991.

3. Li $\mathrm{X}$, et al. Epitranscriptome sequencing technologies: Decoding RNA modifications. Nat Methods. 2016; 14: 23-31.

4. Saletore $Y$, et al. The birth of the Epitranscriptome: deciphering the function of RNA modifications. Genome Biology. 2012; 13: 175.

5. Machnicka MA, et al. MODOMICS: a database of RNA modification pathways-2013 update. Nucleic Acids Res. 2013; 41: 262-267.

6. Ianniello Z, et al. N6-Methyladenosine Role in Acute Myeloid Leukaemia. Int J Mol Sci. 2018; 19: 2345. 
7. Garitano-Trojaola A, et al. Long non-coding RNAs in haematological malignancies. Int J Mol Sci. 2013; 14: 15386-15422.

8. Agirre X, et al. Epigenetic regulation of miRNA genes in acute leukemia. Leukemia. 2012; 26: 395403.

9. Presner JR, et al. The emergence of IncRNAs in cancer biology. Cancer Discov. 2011; 1: 391-408.

10. Agirre $X$, et al. Long non-coding RNAs discriminate the stages and gene regulatory states of human humoral immune response. Nat Commun. 2019; 10: 821.

11. Ponting CP, et al. Evolution and functions of long non-coding RNAs. Cell. 2009; 136: 629-641.

12. Huarte $M$, et al. A large intergenic long non-coding RNA induced by p53 mediates global gene repression in the p53 response. Cell. 2010; 142: 409-419.

13. Gendrel AV, et al. Noncoding RNAs and epigenetic mechanisms during X-chromosome inactivation. Annu Rev Cell Dev Biol. 2014; 30: 561-580.

14. Rinn JL, et al. Functional demarcation of active and silent chromatin domains in human HOX loci by non-coding RNAs. Cell. 2007; 129: 1311-1323.

15. Khalil AM, et al. Many human large intergenic noncoding RNAs associate with chromatin-modifying complexes and affect gene expression. Proc Natl Acad Sci USA. 2009; 106: 11667-11672.

16. Lyu $\mathrm{Y}$, et al. Dysfunction of the WT1-MEG3 signaling promotes AML leukemogenesis via p53dependent and -independent pathways. Leukemia. 2017; 31: 2543-2551.

17. Alvarez-Dominguez $\mathrm{JR}$, et al. Long non-coding RNAs during normal and malignant hematopoiesis. Int J Hematol. 2014; 99: 531-541.

18. Kim WY, et al. The regulation of INK4/ARF in cancer and aging. Cell. 2006; 127: 265-275.

19. Kotake $Y$, et al. Long non-coding RNA ANRIL is required for the PRC2 recruitment to and silencing of p15(INK4B) tumor suppressor gene. Oncogene. 2011; 30: 1956-1962.

20. Yu W, et al. Epigenetic silencing of tumor suppressor gene p15 by its antisense RNA. Nature. 2008; 451: 202-206.

21. Sun $L Y$, et al. LncRNA ANRIL regulates $A M L$ development through modulating the glucose metabolism pathway of AdipoR1/AMPK/SIRT1. Mol Cancer. 2018; 17: 1-6.

22. Newcomb LF, et al. Performance of PCA3 and TMPRSS2:ERG urinary biomarkers in prediction of biopsy outcome in the Canary Prostate Active Surveillance Study (PASS). Prostate Cancer Prostatic Dis. 2019 Jan 21. doi: 10.1038/s41391-018-0124-z.

23. Corey DR, et al. Non-coding RNAs as drug targets. Nat Rev Drug Discov. 2017; 16: 167-179.

24. Shafik A, et al. The emerging epitranscriptomics of long noncoding RNAs. Biochim Biophys Acta. 2016; 1859: 59-70.

25. Song J, et al. Chemical Modifications to RNA: A New Layer of Gene Expression Regulation. ACS Chem Biol. 2017; 12: 316-325.

26. Frye $\mathrm{M}$, et al. RNA modifications: what have we learned and where are we headed? Nat Rev Genet. 2016; 17: 365-372.

27. Meyer KD, et al. The dynamic epitranscriptome: N6-methyladenosine and gene expression control. Nat Rev Mol Cell Biol. 2014; 15: 313-326.

28. Morena F, et al. Above the epitranscriptome: RNA modifications and stem cell identity. Genes. 2018; 9: 1-28.

29. Patil DP, et al. Reading m6A in the transcriptome: m6A-binding proteins. Trends Cell Biol. 2018; 28: 113-127.

30. Adhikari S, et al. m(6)A: Signaling for mRNA splicing. RNA Biol. 2016; 13: 756-759.

31. Zhou KI, et al. N6-methyladenosine modification in a long non-coding RNA hairpin predisposes its conformation to protein binding. J Mol Biol. 2016; 428: 822-833.

32. Zhao BS, et al. Post-transcriptional gene regulation by mRNA modifications. Nat Rev Mol Cell Biol. 2017; 18: 31-42.

33. Davalos V, et al. SnapShot: Messenger RNA Modifications. Cell. 2018; 174: 498-498.

34. Safra $M$, et al. The $m^{1} A$ landscape on cytosolic and mitochondrial $m R N A$ at single-base resolution. Nature. 2017; 551: 251-255.

35. Cheng JX, et al. RNA cytosine methylation and methyltransferases mediate chromatin organization and 5-azacytidine response and resistance in leukaemia. Nat Commun. 2018; 9: 1163.

36. Weng $\mathrm{H}$, et al. METTL14 Inhibits Hematopoietic Stem/Progenitor Differentiation and Promotes Leukemogenesis via mRNA m6A Modification. Cell Stem Cell. 2018; 22: 191-205.

37. $\mathrm{Vu}$ LP, et al. The N6-methyladenosine (m6A)-forming enzyme METTL3 controls myeloid differentiation of normal hematopoietic and leukemia cells. Nature Med. 2017; 23 b: 1369-1376.

38. Morlando M, et al. Long non-coding RNAs: New players in hematopoiesis and leukemia. Front Med (Lausanne). 2014; 2: 23 